\title{
技術者と教員の相互連携による初等教育段階での 『モノづくり教育』とその実践
}

"Monodukuri Education" in the Elementary Educations under the Mutual Coordination between Engineers and Teachers

$\begin{array}{clll}\text { 伊 藤 昭 夫*1 } & \text { 井 上 靖 浩*1 } & \text { 定 光 優 友*1 } \\ \text { Akio ITO } & & \text { Yasuhiro INOUE } & \text { Yusuke SADAMITSU }\end{array}$

As one of the means to improve the number of children who do not like mathematics or science, it is necessary that there are classes to make children recognize the importance of "Monodukuri" and its social meanings. In order to realize such classes, we propose a new method of classes which are practiced under the mutual coordination between engineers and teachers. By this methods, both engineers and teachers are able to have classes with sharing the education objective, for example, to elevate the interests of children in the technology or the activity of a social contribution. We call such classes "Monodukuri Education". In the present paper, we state the results obtained by "Monodukuri Education", which was practiced under the cooperation of Higashihiroshima Civic Takamigaoka Elementary School, and the subjects in the next step.

Keywords : “Monodukuri Education”, elementary education, coordination, engineers, teachers キーワード：『モノづくり教育』, 初等教育, 連携, 技術者, 教員

\section{1. 序論}

今日，子どもたちの理数系離れ・理工系離れが極め て深刻な問題となり, 学校教育の場に押いて早急かつ効 果的な対策を講じなければならない. そのような状況の 中で, 我々は「モノづくり」の目的とその重要性に着目 し，初等教育段階から授業の中に「モノづくり」などの 工学的要素を取り入れた算数・数学的体験活動を導入 する必要があると考え，地域の子どもたちを対象に様々 な活動 ${ }^{1)}$ 実践している，その理由として，第一に「モ ノづくり」などの体験活動を通して数学や理科の基本的 な知識の使い方を示すことが可能となることが挙げられ る. 第二に,「モノづくり」の楽しさや難しさを体験さ せることによって，子どもたちの科学技術への興味・関 心を引き出すことが出来る．第三に，「モノづくり」で は技術力の向上は言うまでもなく, 人が多様な環境の下 で社会生活を営むために「モノ」をどのように作り出 し，「モノ」をどのように活かし，「モノ」によって何に 貢献できるのかを考えようとする態度をも育成すること が出来る，例えば，福祉分野においては，介護・介助支 援ロボットを設計・製作するための卓越した技術力は言 うまでもなく，被介護者が本来必要とする支援を見極 め，それをどのように具現化してゆくかを考察する豊か

平成 19 年 2 月 16 日受付

※ 1 近畿大学工学部電子情報工学科

\section{な人間性が必要とされるからである.}

従って, 初等教育段階における授業で「モノづくり」 を取り扱うことは子どもたちの豊かな人間性などの 『生きる力』を育成することにもつながる.

しかし，単に技術者に依頼した「モノづくり」の授 業では，子どもたちの活動が作品の製作に偏ってしま う傾向があるようである。その主たる原因は，「モノ づくり」教育が単発的な授業となるため, 図 1 のよう に技術者が教育目標の設定や授業計画，特に授業時間 数, などを教員に一任せざるを得なかったからではな いかと考えた。

実際，たとえ素晴らしい教材を提供したとしても授 業時間数や教室環境が不十分だったために，満足のい

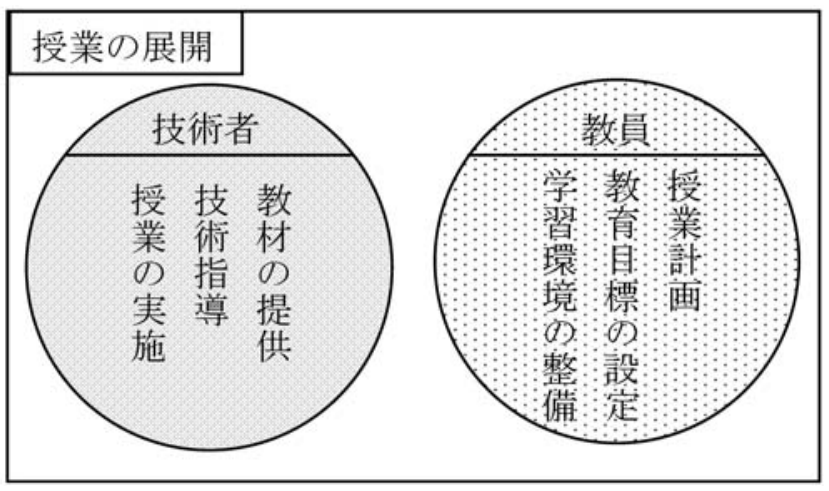

図 1 「モノづくり」教育における授業デザイン 


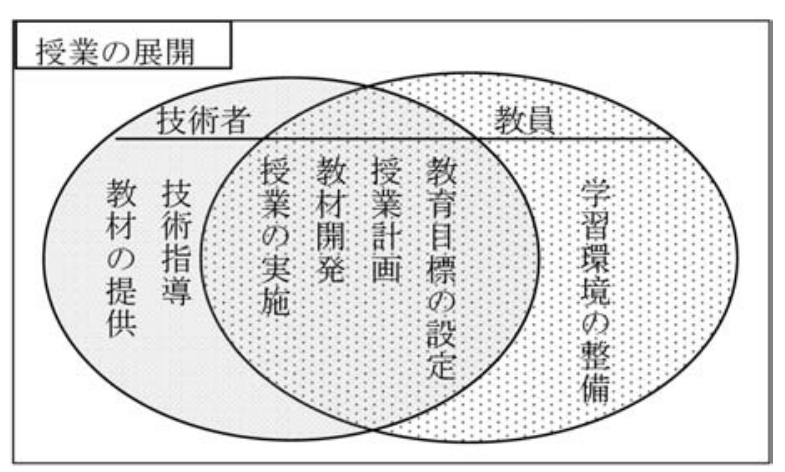

図 2 『モノづくり教育』における授業デザイン

く結果が得られなかったという経験を持つ技術者は少 なくないであろう.

そこで, 図 1 の手法の「モノづくり」教育では達成 できなかった教育目標を実現するために，我々は技術 者及び教員のどちらか一方を授業者とするのではな く，相補関係の上で授業を展開する手法を提案する. 具体的には, 図 2 に示すように技術者と教員は協力し て教育目標を設定し，その教育目標を達成するための 教材を開発する。そして，それらを踏まえた上で授業 計画を作成する．実際の授業においては，技術者は主 に子どもたちの「モノづくり」活動における技術面の 指導を担当し，教員は子どもたちが安全かつ円滑に 「モノづくり」活動を実施できる環境を整える。そし て，技術者と教員は協力して授業を実施し，子どもた ちの技術力の向上のみならず，内面的な成長を図る. 我々はこのような授業デザインを採用した教育を『モ ノづくり教育』と呼ぶことにする.

本論文では，東広島市立高美が丘小学校との連携に よる『モノづくり教育』の実践事例とその実践で用い た評価手法について説明するとともに, 本実践で得ら れた結果について考察する。

\section{2. 実践事例}

本章では, 東広島市立高美が丘小学校との連携のも とで実施した『モノづくり教育』について解説する.

単 元 名:のぞみ学習講座「夢々ロボット」

日 時：計 8 回（表 1参照）

教 員 : 伊藤昭夫, 井上靖浩

技 術 者 : 定光優友

参加児童 : 5 名

\section{1 教育目標の設定}

技術者と教員は協議の上で本講座の教育目標を「将 来, 福祉・環境問題・世界平和などへの社会貢献を意 識したロボットを作りたいと思う豊かな心を持った子 どもたちを育成する」に設定した。

\section{2 教材開発}

技術者の助言をもとに，本教育目標を達成するため の教材としてセンサに今回は着目した。 その理由とし て，センサは自動ドアや自動車など身近な「モノ」に
利用されているだけでなく, 光センサや音センサなど のように人間の目や耳の役割を果たす可能性を秘めて いるからである。

そして，本活動で使用するロボットの採用にあたっ ては, 事前打合せの段階で, 技術者だけでなく教員も そのロボットを作成し, 小学校高学年の児童ならば十 分に回路基板の作成段階から活動できると判断された ロボットに限定する。 そして, 技術者と教員はこの事 前打合せで得られた知見をもとに，子どもたちにとっ てわかりやすいロボットを製作するための配布資料を 作成する.

\section{3 授業計画}

技術者と教員は協議の上，本活動の授業計画を表 1 に示すと抢り作成した。表 1 に打ける記号 Aは「児童 の主な学習活動」, 記号 Bは「教員の主な評価項目」 をそれぞれ表す。

\section{表 1 授業計画}

\begin{tabular}{|c|c|c|}
\hline 時 & & 主な学習活動 \\
\hline \multirow{3}{*}{1} & \multicolumn{2}{|c|}{$\begin{array}{l}\text { 本授業への導入とハンダ付けの練習 } \\
\text { (平成 } 17 \text { 年 } 10 \text { 月 } 21 \text { 日) }\end{array}$} \\
\hline & A & $\begin{array}{l}\text { (1)センサについて知る. } \\
\text { (2)本授業の内容に興味・関心を持つ. }\end{array}$ \\
\hline & B & $\begin{array}{l}\text { ロボットに興味・関心を持つとともに, ハンダ } \\
\text { 付けの方法と危険性を理解する. }\end{array}$ \\
\hline \multirow{3}{*}{2} & \multicolumn{2}{|r|}{ ハンダ付けの練習（平成 17 年 11 月 18 日） } \\
\hline & \multirow[b]{2}{*}{ B } & $\begin{array}{l}\text { (1)ハンダ付けの危険性を再度確認する. } \\
\text { (2)回路基板に電子素子をハンダ付けするための } \\
\text { 技術を習得する. }\end{array}$ \\
\hline & & $\begin{array}{l}\text { 的確にハンダ付けをするための技術を身につけ } \\
\text { る. }\end{array}$ \\
\hline \multirow[b]{3}{*}{4} & \multicolumn{2}{|r|}{$\begin{array}{l}\text { 基板のハンダ付け } \\
\text { (平成 } 17 \text { 年 } 11 \text { 月 } 25 \text { 日・12 月 } 9 \text { 日) }\end{array}$} \\
\hline & A & 自ら進んでハンダ付けを行う。 \\
\hline & B & $\begin{array}{l}\text { (1)自ら進んでハンダ付けを行っている. } \\
\text { (2)チエックシートを確実に実行している. } \\
\text { (3)常に安全面に配慮している. }\end{array}$ \\
\hline \multirow{3}{*}{5} & \multicolumn{2}{|r|}{ 動作確認（平成 17 年 12 月 16 日） } \\
\hline & A & 回路基板の動作確認を行う。 \\
\hline & & 回路基板が正常に動作する. \\
\hline \multirow{3}{*}{6} & \multicolumn{2}{|r|}{ ロボットの起動（平成 18 年 1 月 27 日） } \\
\hline & A & $\begin{array}{l}\text { (1)自分で描いた線上を走らせる。 } \\
\text { (2)作成したロボットセンサが人間の目の役割 } \\
\text { を果たしていることを理解する. }\end{array}$ \\
\hline & B & $\begin{array}{l}\text { (1)ロボットが正常に動作する. } \\
\text { (2)センサの役割を理解している. }\end{array}$ \\
\hline \multirow{3}{*}{7} & \multicolumn{2}{|r|}{ 発表資料の作成（平成 18 年 2 月 10 日） } \\
\hline & A & $\begin{array}{l}\text { 情報機器を活用して, 本授業の感想などプレゼ } \\
\text { ンテーション資料を作成する. }\end{array}$ \\
\hline & B & $\begin{array}{l}\text { 情報機器を利用して，発表資料を作成すること } \\
\text { ができる. }\end{array}$ \\
\hline \multirow{3}{*}{8} & \multicolumn{2}{|r|}{ プレゼンテーション（平成 18 年 3 月 3 日） } \\
\hline & A & プレゼンテーションを行う. \\
\hline & B & $\begin{array}{l}\text { 自分の意見を明確に相手に伝えることができ } \\
\text { る. }\end{array}$ \\
\hline
\end{tabular}




\section{4 技術指導}

「モノづくり」の楽しさや難しさを子どもたちに認 識させるために，本授業では回路基板を作成する段階 から，光センサ搭載型のロボットを製作する．その作 業を効率よく安全に実施するために, 技術者はハンダ 付けや電子素子の取り付け方法など技術面の指導を主 に担当する.

\section{5 学習環境の整備}

本活動において，子どもたちはハンダ付けを授業だ けでなく家庭でも実施しなければならない，教員はそ の一連の活動を安全かつ円滑に行うための環境を整備 しなければならない，実際には，安全にハンダ付けを 行うための資料作成や教室内に打ける電気コード . 机・ハンダゴテ等の配置を工夫しなければならない.

さらに, 最も重要なことは, 子どもたちが家庭でも 安全面に配慮した活動ができる能力を育成しなければ ならないことである，今回は，その能力を育成するた めに, 学習活動の中に自己評価活動 ${ }^{2)}$ を取り入れるこ とにした。

\section{3. 評価方法}

本章では，本実践において採用した評価手法につい て説明する。

\section{1 ハンダ付け段階における評価}

第 $3 \cdot 4$ 時間目において教員が設定した評価項目と それぞれの項目に対して教員が採用した評価方法につ いて述べる。

評価項目(1)：比較分析能力の評価

技術者のハンダ付けを観察し, 自分のハンダ付けと 正しく比較することができる．もし，自分のハンダ付 けの方法に誤りがある場合には，その誤りを修正する ことによって自己のハンダ付けの技術を向上させよう とする態度を評価する，実際には，次のような方法で 評価する.

ハンダ付けに扔ける手順などの間違いの個数が技術 者のハンダ付けを観察する前と後でどれだけ減少した かを観察し, 次式

$100(\mathrm{a}-\mathrm{b}) / \mathrm{a}$

で数值化する.ここで, $\mathrm{a}$ は「観察前の間違いの個数」, $\mathrm{b}$ は「観察後の間違いの個数」を表す。ただし，「 $\mathrm{a}=$ $\mathrm{b}=0\rfloor$ の場合は 100 点, $\lceil\mathrm{b}>\mathrm{a} 」$ の場合は 0 点とする.

例えば，4時間目に扔けるA君の学習活動を観察 すると，技術者のハンダ付けを観察する前には5箇所 あった間違いが，観察後には 2 箇所に減少した，従っ て, 4 時間目の $\mathrm{A}$ 君の評価は

$$
100(5-2) / 5=60
$$

となる。

評価項目(2)：自己評価活動の評価

教員が机間指導している学習環境の中で，自分の八 ンダ付けの技術を自己評価する，実際，子どもたちに
ハンダ付け時の注意事項などを項目別に記入したチェ ックシートを配布する。 子どもたちはそのチェックシ ートに記されている項目に注意を払いながらハンダ付 けを実施する。そして，1回のハンダ付けが終了する たびにチェックシートに自己評価を三段階方式「○： できた」・「 $\triangle$ : 普通」・「メ：できなかった」で記入す る。この際, 評価に厳しい子どもと評価に甘い子ども がいることが容易に想像されるであろう. 教員は, 子 どもとコミュニケーションをとりながら，自己評価が 的確にできるようになるための指導を繰り返し行う. この評価手法は共同自己評価 ${ }^{2)}$ と呼ばれる.

それと同時に，教員は子どもたちの自己評価活動を 次の方式で数值化する．前述のように，子どもたちは ハンダ付けを 1 回終了するたびにチェックシートに自 己評価を記入する。 しかし，ハンダ付けに熱中するあ まり，その評価活動を忘れることがある。 そこで，今 回は子どもたちが何回目の自己評価活動を忘れたかを 調査し, 評価することとした. 数值化の手法としては, 100 点から「1回目: 5 点 $\cdot\ulcorner 2$ 回目 : 10 点 $」\ulcorner 3$ 回 目：15点」・「4 回目以降：20点」減点するという方 式を採用した。

例えば， 3 時間目における B 君の自己評価活動を観 察すると, $\mathrm{B}$ 君はこの時間に 6 個の電子素子のハンダ 付けを行った。 その際, 2 回目・ 4 回目・ 6 回目の自 己評価活動を忘れた。従って，3 時間目のB 君の評価 は

$$
100-(10 \times 1+20 \times 2)=50
$$

となる。

評価項目 (3)：技術力の評価

安全かつ確実に電子素子を回路基板にハンダ付けで きたかを次のような減点方式で数值化する。まず, 最 初の持ち点を安全面に対する配慮 60 点, ハンダ付け の確実さ 40 点, 合計 100 点とする. そして, 安全面に 対する配慮が欠けた場合は 1 回 20 点, ハンダ付けの 確実さにおいては 1 回の失敗で 5 点減点する.

例えば, 4 時間目におけるC君の活動を観察すると, C君はこの時間にハンダ付けを計 8 個行った.この際, 安全面に対する配慮が 1 回欠け, ハンダ付けの確実さ という点においては 2 回失敗した。従って, 4 時間目 のC君の評価は,

$$
(60-20 \times 1)+(40-5 \times 2)=70
$$

となる.

評価項目 (4)：自主性

ハンダ付けを繰り返し練習することによって, 積極 的に自己の技術力を向上させようとしているかを今回 は次の手法で数值化した. 子どもたちが自己の技術を 向上させようとしている活動を，ハンダ付けした電子 素子の個数と技術者への質問回数で判断した. 実際に は,「回路基板への電子素子のハンダ付け：10点」・ 「練習基板への電子素子のハンダ付け： 5 点」・「ハン 
表 2 教員による評価結果

\begin{tabular}{|c|c|c|c|c|c|c|}
\hline & $\mathrm{A}$ 君 & $\mathrm{B}$ 君 & $\mathrm{C}$ 君 & $\mathrm{D}$ 君 & $\mathrm{E}$ 君 & 平均 \\
\hline (1) & 63.75 & 71.25 & 68.75 & 63.75 & 66.25 & 66.75 \\
\hline (2) & 61.25 & 62.50 & 73.75 & 66.25 & 73.75 & 67.50 \\
\hline (3) & 57.50 & 66.25 & 71.25 & 62.50 & 63.75 & 64.25 \\
\hline (4) & 72.50 & 62.50 & 72.50 & 68.75 & 71.25 & 69.50 \\
\hline (5) & 73.75 & 100.0 & 93.75 & 76.25 & 81.25 & 85.00 \\
\hline 平均 & 65.75 & 72.50 & 76.00 & 67.50 & 71.25 & \\
\hline
\end{tabular}

ダ付け時における技術者への質問：5点」として採点 した。

例えば，3時間目におけるD君の学習活動を観察す ると，D君はこの時間に回路基板へ 4 個，練習基板へ 5 個の電子素子をハンダ付けし，技術者への質問は 2 回であった。従って，3時間目のD君の評価は

$$
(10 \times 4)+(5 \times 5)+(5 \times 2)=75
$$

となる。

評価項目(5)：授業態度

授業に臨む基本的な姿勢を「先生の話を聞く」・ 「忘れ物をしない」・「私語を慎む」という３項目と した。そして，「先生の話を聞いていない場合：20 点」・「配布資料を忘れた場合：10点」・「ロボッ 卜を忘れた場合：20点」・「私語をした場合：5点」 とし，減点方式を採用した。

例えば，4 時間目における $\mathrm{E}$ 君の学習活動を観察す ると，E君は配布資料を忘れ，授業中に 2 回私語をし た。従って，4時間目における $\mathrm{E}$ 君の評価は

$$
100-(10+5 \times 2)=80
$$

となる。

2 人の教員による 5 人の児童の評価（平均点）をま とめると表 2 にようになる.

\section{2 ハンダ付け時における自己評価の評価}

子どもたちが回路基板へ電子素子をハンダ付けした 際の自己評価の結果を表 3 及び表 4 に示す。ここで, 注意しなければならないことは, 回路基板（小）への 電子素子のハンダ付けは第 3 ・4 時間目の活動でほと んど完了したが，回路基板（大）への電子素子のハン ダ付けは基本的には家庭での活動となっている。結果 として，子どもたちは授業で学習した内容を家庭で振 り返りながら, 安全面に配慮しつつ, 自己評価を繰り 返しながら作業を実施したことになる。このような状 況での自己評価は共同自己評価と区別するために完全 自己評価 ${ }^{2)}$ と呼ばれる.

表 3 から，子どもたちは授業という環境の中で共同 自己評価を実行する能力は十分にあると言える。しか し，表 4 が示すように家庭など教員の支援がない環境 のもとで完全自己評価を実行する能力はまだ不完全で ある。実際，D君はチェックシートによる自己評価を ほとんど実施していない。また，チェック項目のない 場所に○を記入したり，チェックシートには○をつけ
表 3 回路基板（小）における（共同）自己評価

\begin{tabular}{|c|c|c|c|c|c|c|}
\hline 基板(小) & $\mathrm{A}$ 君 & $\mathrm{B}$ 君 & $\mathrm{C}$ 君 & $\mathrm{D}$ 君 & $\mathrm{E}$ 君 & 合計 \\
\hline$\bigcirc$ & 98 & 61 & 98 & 13 & 96 & 366 \\
\hline$\triangle$ & 0 & 8 & 0 & 1 & 1 & 10 \\
\hline$\times$ & 0 & 1 & 0 & 0 & 1 & 2 \\
\hline 合 計 & 98 & 70 & 98 & 14 & 98 & \\
\hline チェックなし & 0 & 28 & 0 & 84 & 0 & 112 \\
\hline 総 数 & \multicolumn{7}{|l}{} \\
\hline
\end{tabular}

表 4 回路基板（大）における完全自己評価

\begin{tabular}{|c|c|c|c|c|c|c|}
\hline 基板 $(大)$ & $\mathrm{A}$ 君 & $\mathrm{B}$ 君 & $\mathrm{C}$ 君 & $\mathrm{D}$ 君 & $\mathrm{E}$ 君 & 合計 \\
\hline$\bigcirc$ & 493 & 481 & 494 & 312 & 493 & 2273 \\
\hline$\triangle$ & 1 & 11 & 0 & 0 & 1 & 13 \\
\hline$\times$ & 0 & 2 & 0 & 0 & 0 & 2 \\
\hline 合 計 & 494 & 494 & 494 & 312 & 494 & \\
\hline チェックなし & 0 & 0 & 0 & 182 & 0 & 182 \\
\hline 総 数 & \multicolumn{7}{|c|}{494} \\
\hline
\end{tabular}

ているにもかかわらず電子素子の向きを間違えてハン ダ付けしたりしている児童も見受けられた。つまり， 配布資料やチェックシートを熟読せずに回路基板に電 子素子をただ単にハンダ付けしている可能性が非常に 高く，ロボット作成という「モノづくり」活動のみが 子どもたちの学習活動の中心となっていることが容易 に推察される.

\section{3 ハンダ付け時における技術者の評価}

技術者が子どもたちに実際に行った対応をまとめた ものが表 5 である.

\begin{tabular}{|c|c|c|c|}
\hline 素子名 & 児童 & 修理事項 & 対応内容 \\
\hline $\begin{array}{c}\text { LED3 } \\
\text { (3 時間目) } \\
\text { 小基板 }\end{array}$ & $\mathrm{D}$ 君 & $\begin{array}{l}\text { 差し込み具合の } \\
\text { 確認 }\end{array}$ & $\begin{array}{l}\text { 差込が甘かったの } \\
\text { で奥まで差し込む }\end{array}$ \\
\hline $\begin{array}{c}\text { LED3 } \\
\text { (3 時間目) } \\
\text { 小基板 } \\
\end{array}$ & B 君 & 電子素子の浮き & $\begin{array}{l}\text { ハンダを取り除き, } \\
\text { 足の開きが甘かっ } \\
\text { たことを伝える }\end{array}$ \\
\hline $\begin{array}{c}\text { LED3PTR2 } \\
\text { (3 時間目) } \\
\text { 小基板 }\end{array}$ & $\mathrm{D}$ 君 & 電子素子の浮き & $\begin{array}{l}\text { ハンダを溶かし, 電 } \\
\text { 子素子の浮きを上か } \\
\text { ら押さえて修正した }\end{array}$ \\
\hline $\begin{array}{c}\text { ピン端子 } \\
\text { (3 時間目) } \\
\text { 小基板 }\end{array}$ & A 君 & $\begin{array}{l}\text { ピン端子の取り } \\
\text { 付け方の指導 }\end{array}$ & $\begin{array}{l}\text { ピン端子のハンダ } \\
\text { 付けを実際に行う }\end{array}$ \\
\hline $\begin{array}{c}\text { ピン端子 } \\
\text { (3 時間目) } \\
\text { 小基板 } \\
\end{array}$ & B 君 & イモハンダ & $\begin{array}{l}\text { ハンダごてをあて } \\
\text { ハンダを広げる }\end{array}$ \\
\hline $\begin{array}{c}\text { 抵抗 } \\
(4 \text { 時間目) } \\
\text { 大基板 }\end{array}$ & B 君 & $\begin{array}{l}\text { ハンダ付けの修 } \\
\text { 正の指示 }\end{array}$ & $\begin{array}{l}\text { 修正せずに作業を } \\
\text { 続行させた }\end{array}$ \\
\hline $\begin{array}{c}\text { TR6 } \\
\text { (4 時間目) } \\
\text { 小基板 }\end{array}$ & D 君 & $\begin{array}{l}\text { 電子素子の向き } \\
\text { が逆 }\end{array}$ & $\begin{array}{l}\text { 交換せずに付け直 } \\
\text { した }\end{array}$ \\
\hline
\end{tabular}

表 5 技術者の対応内容 
本活動における 1 つのきな問題点でもあるのだ が，本論文では技術者が子どもたちをどのような手法 で評価し，数值化すればよいかを提案するに至ってい ない. ハンダ付けを通しての技術者とのコミュニケー ションの様子や子どもたちの技術力は表 5 を参考にし て評価できる.しかし, コミュニケーションを通して, 子どもたちの内面的な活動を活発にするために技術者 はどう働きかければよいのかが問題として残り, 結果 として，子どもたちの内面的な成長を評価することが できなかった.

実際，技術者の感想は『本授業を通して最も難しか ったことは, 技術力の向上に加えて, 子どもたちの心 の成長という内面的な活動を教育目標に加えた結果, 技術者としてどのように子どもたちとコミュニケーシ ヨンを図り, 如何にして教育目標に到達させるのか, その手法を確立することであった，実際，技術面以外 の評価方法に関して多くの課題が残った。 また, 教育 目標を見据えた児童への発問などの指導方法を考える ことが非常に難しかった．技術面の指導はほぼ問題無 く実施できたが，「モノづくり」を通して人の役に立 ちたいと思う豊かな心を技術者としてどのように育成 するかは今後の重要な検討課題であろう.』である.

\section{4 教育目標の達成度の評価}

子どもたちが本授業の教育目標に対してどこまで到 達したかを評価する。そのためにアンケートを実施し た. 以下に, アンケート項目とそのアンケートに対す る子どもたちの回答を示す，ただし，子どもたちの回 答に扔ける誤字・脱字等についてはそのまま記述する こととする.

（1）アンケート 1 : 今回の『のぞみ学習』でロボット を作りましたね元ロボットを作ってみて楽しかった ことや難しかったことなど, 感想を書きましょうっ 本項目に対する子どもたちの回答をまとめると次の ようになる。

(a) A君の回答

ぼくは最初, ハンダ付けがとても難しそうだと思っ ていました。でも,やってみたら, 案外楽しいな, と 思いました。一番難しかったのは基板がちゃんと動く かどうかをたしかめる事です。ぼくはハンダ付けがい がいと自分でも上手だなと思いました。ぼくは，こう いったロボット作りをいつかしたいと思っていまし た。でも，のぞみでできるとは思っていませんでした。 できると知った時にはとてもうれしかったです。また ロボット作りがしたいです.

(b) B君の回答

僕はロボットをつくるとき，まず，ハンダづけをす ることをしってはじめは, できるかどうかが心配でし た。やってみると予想通り下手だったけど練習してあ る程度まではうまくなれたのでよかったです，そして 動作確にんやメカのくみたてなどはとても苦労しまし
た. 動作確にんでは説明書どおりに発光ダイオードが 光らずに直すのにとても時間を使いました．メカのく

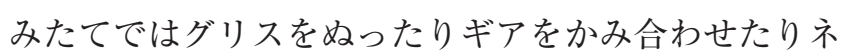
ジでとめたり, 色々とこまかい作業がつづき, 目や指 がとてもつかれました。でも，その分，できたときは うれしかったです．色々失敗したりしたけれど，ロボ ットづくりはとてもおもしろく良い体験となったので よかったです。

(c) C君の回答

ロボット作りで一番むずかしかったのは，ハンダ付 けです，何がむずかしかったかというと，ハンダ付け をするときに，電子素子がまがってついてしまったり したときに，修理が，なかなか上手にできなかったか らです。楽しかったこともあります。楽しかった作業 は，ボディーの組み立てです，ぼくは，工作が好きな ので, プラスチックを切るときにできる，抄うとつを けずる作業や, 組み立てていくうちに, ロボットの形 がどんどんできていく様子を見るのが，たまらなく楽 しかったです，感心したこともあります，基板は，小 さいけれど，基板が完成するまでに，一つでも失敗を すれば，ロボットは動かなくなると教わりました，だ から, 基板は, ロボットの中で，一番大切なところた と思います。それで，ロボットは奥が深いなあと思い ました。

(d) $\mathrm{D}$ 君の回答

ハンダごてやハンダ付けをやったことがなくてすこ しむずかしくて，でもやっているうちになれてたのし くなりました。

(e) E君の回答

最初はこれくらいのことならできると思っていたけ どハンダをするのは難しく少しでも失敗をすると動か なくなると言っていたから緊張して少しできませんで した。でも慣れてくるとすぐにできるようになりまし た。だけど素子一つ一つちゃんとした場所にやらない とうごかないことがわかりました，だからちゃんと見 る力, 読む力がついたのでよかったです.

（2）アンケート 2：今回ロボットを作ってみて, どん なロボットを作ってみたくなったかな？さあ〜作っ てみたいロボットの絵を描いてみよう〜 D

本項目に対する子どもたちの作品として, 本論文で は対象的な A君と B君の作品を提示する.

(a) A君の作品（図 3 )

形も色も動き方もへビそっくりにする．まわりをや わらかいゴムでかこんで本物らしくする，人をおどか す.

（b）B君の作品（図 4)

1 ）車にかわる

2 ) 生活に必要な物を中に入れている（器ぐ・道 具・飲料水など)

3 ）けいたい電話の働きもする 


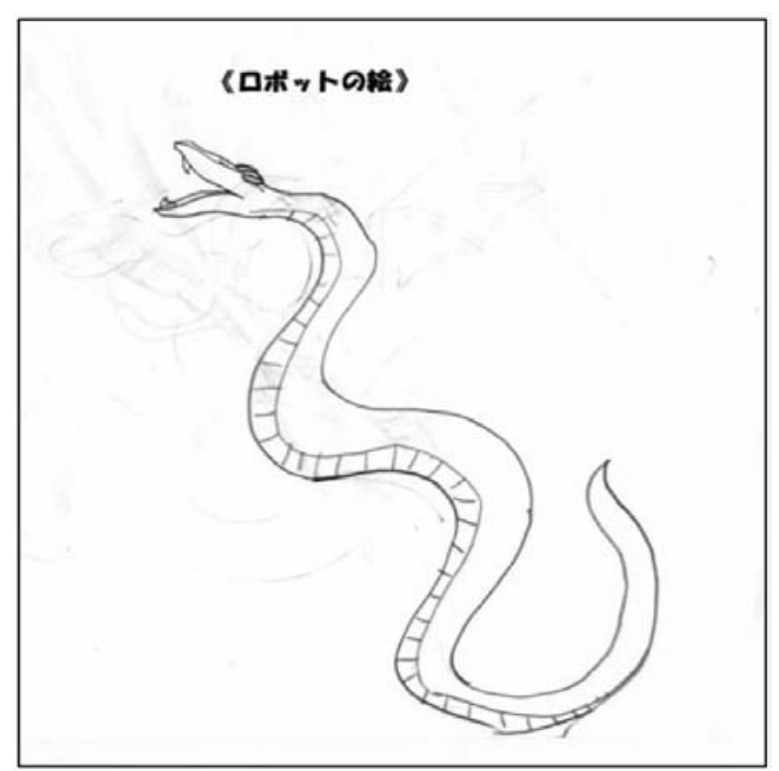

図 3 A君の作品

4） 1,000度までならたえられるたい熱せい

$5 ） 1,000 \mathrm{~kg}$ までの物なら全てもてる

以上のアンケート結果を総合すると, ロボット製作 という「モノづくり」がまだ優先されており，本来の 教育目標に達している部分が少ないのではないかと考 えられる. 実際，A君はロボットやハンダ付けに対す る興味は非常に高いが，その一方で教育目標に挙げて いた社会貢献という部分にまで思いが至っていないと 判断せざるを得ない.

その一方で, B君はハンダ付けの難しさを感じてい る一方で，ロボットを利用しての社会貢献意識が芽生 え始めていると言える. 実際, B 君はロボットの機能 1 ）－5）について説明する際, 芸予地震の被害につ いて触れていたからである。従って，B君については 我々の教育目標にほぼ到達できたと評価できる.

\section{4. 分析および提言}

我々が提案する『モノづくり教育』は技術者の授業 への関り方を拡げたものである。実際，2章で述べた ように『モノづくり教育』では，授業デザインの段階 で技術者と教員が教育目標の設定・教材開発・授業計 画を協力して実施する，従って，技術者は「モノづく り」活動の教育目標を理解したうえで, 子どもたちに 技術指導ができる．結果として，専門的な技術力を持 たない教員でも技術者の協力を得ることによって「モ ノづくり」活動を通常の授業として組み込むことが可 能となる.

このような『モノづくり教育』を実現するためには 教育的な配慮を常に意識しながら技術指導ができ，さ らに教員と円滑にコミュニケーションを図ることがで きる技術者の育成が急務である。そして，これは本協 会が実施している『教育士 (工学・技術)』3) の理念に 合致するものである，そして，『教育士 (工学・技術)』

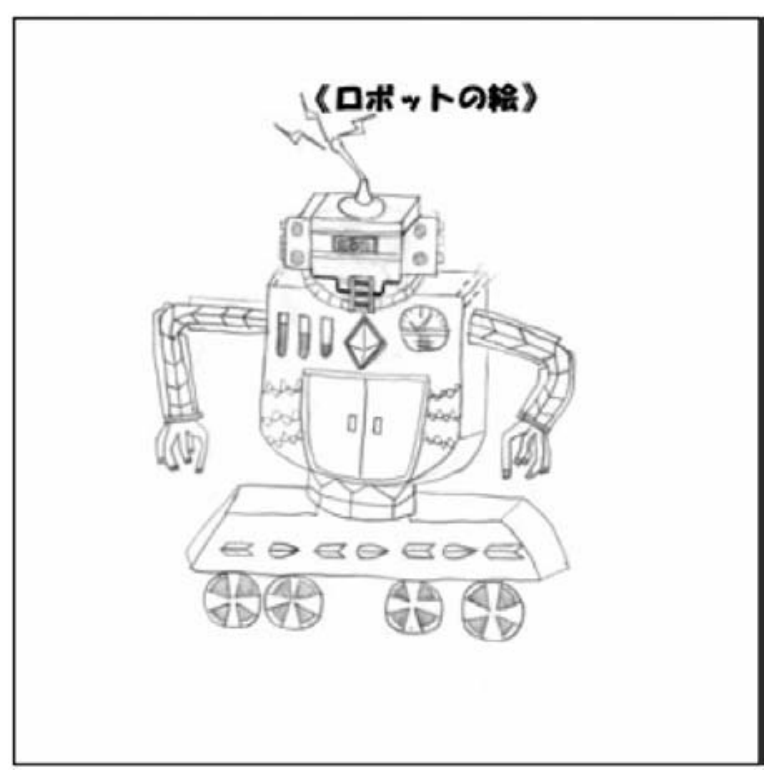

図 4 B君の作品

の資格を持った技術者が学校教育, 特に初等教育, の 場で積極的に子どもたちと『モノづくり教育』を通し てコミュニケーションを図れる環境を一刻も早く整備 することが重要ではないだろうか. 実際, 我々が授業

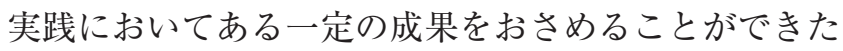
要因の 1 つとして, 本実践を担当した学生（筆頭著者 を除く著者 2 名）が教職課程を履修しているという事 実を挙げることができる。

また，自ら自己を正しく分析し，自分の個性をかけ がえのないものとして尊重し, その伸長を図ることは, 今後の社会を自立して生きていくために必要な力であ る。その力を育成するためには，自己評価活動を取り 入れた『モノづくり教育』が必要不可欠である.

\section{5. 今後の課題}

5. 1 子どもたちの内面的な活動の数值化 アンケートやプレゼンテーションを通して, 子ども たちの内面的な活動を如何に評価し数值化するか, そ の手法の確立が必要不可欠である.

\section{2 他教科との関連}

「モノづくり」=技術科というイメージが強いが, 我々は「モノづくり」を取り入れた活動が様々な教科 の中で実施されることが必要だと考えている．今回の 活動はその導入部に過ぎない，今後は「モノづくり」 の後に続く, 教科教育教材の開発を目指したいと考元 ている.

\section{3 大学教育における課題}

学生の技術力の向上は言うまでもなく, 倫理観など 学生の内面的な心の活動をどう促進し, 教員はどのよ うにその活動を評価すればよいか数值化も含めたその 評価手法を検討しなければならない. 学生のレポート やプレゼンテーションの資料などから学生の内面的な 活動を推測し，ある一定の評価基準に従ってそれを数 
值化し評価する，そして，それらの資料が蓄積される ことによって, より良い評価基準を作り上げていく教 育体制を整えることが重要ではないだろうか。また, 学生の自己評価能力を如何に高めていくかも重要な課 題である.

最後に, 筆頭著者は非線形解析学と数学教育学が尃 門であるが, 工学部においては数学教育も工学教育を 意識した上で展開されることが望ましいと考えてい る. 微分積分や線形代数などを基礎知識として指導す る一方で, 高等学校までに履修してきた数学の知識が どのように工学分野で展開されていくかを意識した数 学教材を開発する必要がある。そして, 高大接続教育 の一環として, その教材を用いた講義を入学時での導 入教育として展開し, 数学を学習する意義を学生に再 認識させる必要性を近年強く感じている。

\section{参 考 文 献}

1) 伊藤昭夫：工学部学生の地域及び初等・中等教育 に执いて果たす役割とその実践, 工学教育, $53-6$, pp. $80-84,2005$

2）荒木 昇, 剣持信幸, 岡崎貴宣 : 自己評価活動を 取り入れた選択数学の教材開発, 数学教育学会誌, $46-3 / 4$, pp. $31-50,2005$

3 ) 吉田 眞: 教育士（工学・技術）審查・実行委員 会報告, 工学教育, $54-6$, pp.31 - 33, 2006

\section{著 者 紹 介}

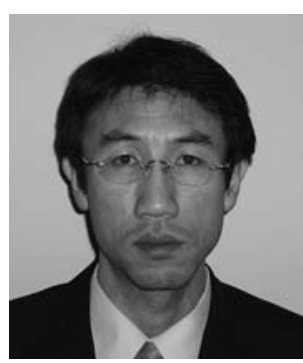

\section{伊藤 昭夫}

学 歴 千葉大学大学院自然科学研究科

職 歴 1998年 4 月 岐阜大学工学部助手 2001 年 4 月 近畿大学工学部講師 2004 年 4 月 近畿大学工学部助教授

専門分野 非線形解析学, 数学教育学

学 位 博士 (理学)

所属学会 日本数学会, 数学教育学会

連絡先 aito@hiro.kindai.ac.jp 